\title{
Yield Loss Assessment in Canola: Effects of Brown Girdling Root Rot and Maggot Damage on Single Plant Yield
}

\author{
H. W. Klein-Gebbinck and D. L. Woods, Agriculture and Agri-food Canada, Beaverlodge Research Farm, Box 29, \\ Beaverlodge, AB TOH 0C0
}

\section{ABSTRACT}

Klein-Gebbinck, H. W., and Woods, D. L. 2002. Yield loss assessment in canola: Effects of brown girdling root rot and maggot damage on single plant yield. Plant Dis. 86:1005-1010.

Single plant yield loss due to brown girdling root rot (Rhizoctonia solani) and cabbage root maggot (Delia spp.) damage was assessed in canola (Brassica rapa cvs. Reward and Tobin) to quantify the effects of root rot on yield and determine whether yield losses due to root rot are compounded by maggot damage. At crop ripening during 1998 and 1999, 2,000 plants from six growers' fields were scored for both root rot and maggot injury. The assessed roots were separated into eight categories constructed by crossing four classes of root rot severity based on degree of girdling and two classes of maggot damage based on percentage of the root surface with maggot tunnels. A ninth category was defined for partially to completely decayed roots for which it was not possible to determine maggot damage. There was no root rot by maggot injury interaction on any of the yield parameters measured. Furthermore, maggots had no adverse effects on yield at the observed damage levels. In contrast, plant weight, seed yield, harvest index, seed size, but not oil content were reduced on plants with completely decayed roots. On average, seed yield was not reduced on plants with roots with nongirdling lesions and superficial nonsinking girdling lesions, but was reduced by $17 \%$ on plants with roots with girdling and sinking lesions, and by $65 \%$ on plants with decayed taproots. Over 2 years, yield losses in growers' fields ranged from 1 to $5 \%$.

Canola (Brassica rapa L.) is an important crop in the Peace River region of Alberta and British Columbia. Rhizoctonia solani Kühn, causal agent of brown girdling root rot (BGRR), and the cabbage root maggot (Delia spp.) are found at varying intensities in all fields in the region (11). There is little published information on yield loss due to BGRR. Turkington and Woods (12) reported that there was a 320 $\mathrm{kg} / \mathrm{ha}$ reduction for each unit increase in the mean BGRR rating, which was based on the degree of root girdling and plant mortality. Because the relationship between the values of the BGRR rating scale and diseased root tissue is not linear (3), the estimated yield loss may be biased. As a consequence, yield loss is likely overestimated at low levels of BGRR and underestimated at high levels of BGRR.

Although cabbage root maggot causes yield loss at high damage levels (e.g., $>50 \%$ root surface with tunnels) (9), it is possible that yield losses may be higher at low levels of maggot damage if maggots increase root rot severity. This may be due to root feeding that provides openings for fungal infection (1). Furthermore, larval

Corresponding author: H. W. Klein-Gebbinck E-mail: kleinh@agr.gc.ca

Accepted for publication 16 May 2002.

Publication no. D-2002-0716-01R

(C) 2002 The American Phytopathological Society movement (9; L. M. Dosdall, Alberta Agriculture, personal communication) may facilitate the spread of inoculum from diseased to healthy roots. The results of previous studies do not always show a positive association between root maggot injury and root rots. There was an increase in soft rot on cruciferous vegetable roots (1), but there was no association between cabbage maggot damage and foot rot on canola (13). There is, however, no quantitative information on the association of root maggot and brown girdling root rot and their effects on yield of canola.

The objectives of this study were to estimate the yield loss in single plants due to cabbage root maggot and brown girdling root rot and their interaction, and to examine the association between brown girdling root rot and cabbage root maggot damage.

\section{MATERIALS AND METHODS}

Single plant harvest index. Harvest index is defined as the ratio of seed yield to total plant shoot biomass. Because seed yield on large plants may be greater than on small plants, and maggots preferentially oviposit on large plants (2), harvest index was used as a measure to further assess yield loss due to maggot damage. To determine the effect of root maggots and root rot on yield, it was necessary to determine the relationship of the harvest index to plant size. At ripening (growth stage 5.3 [4]), 100 individual plants in 1998 and 200 individual plants in 1999 were collected from experimental plots seeded to canola (cv. Tobin) located at the Beaverlodge Research Farm, Beaverlodge, AB. Plants were visually selected such that a range of plant sizes were included in the sample. Each plant was gently pulled and placed in a paper bag and air-dried in the greenhouse for at least 1 month prior to processing. Single plant biomass including the taproot and seed yield were determined for each plant. Harvested plants were assessed for root rot and maggot damage (see below). Data were analyzed using simple linear regression with a zero intercept to derive the single plant harvest index.

Plant collection. At ripening (G.S. 5.3), approximately 1,000 plants in four to six rows were collected from two sites from each of six growers' fields seeded to cv. Horizon in 1998 and cv. Reward in 1999. All fields were located within $50 \mathrm{~km}$ of the Beaverlodge Research Farm. Eleven fields had a cereal (10) or fescue crop (1) in the previous growing season, and one field was summer-fallowed prior to cropping to canola in 1999. Conservation tillage was used on three fields in 1998 and on two fields in 1999, and conventional tillage was used on the other fields. Soil texture varied from clay to clay-loam. In addition, approximately 1,000 plants of $\mathrm{cv}$. Tobin were collected from each of two experimental plots at the Beaverlodge Research Farm in 1998 and 1999. Experimental plots were rotated with cereals and planted using conservation tillage techniques.

Plants were gently pulled from the soil and placed onto plastic sheets with roots aligned on one side. Roots, which were not detached from the plant, were washed to remove soil particles using a fine water spray and assessed within $24 \mathrm{~h}$ of harvest for maggot damage and BGRR. After all roots from one site were assessed, number of plants in each maggot/root rot class were counted, placed in cotton bags, airdried, and stored until processing.

Maggot damage and root rot assessment. While feeding, maggots tunnel on the surface of the root and rarely penetrate the center of the root $(7,13)$. Computergenerated standard area diagrams (Fig. 1) were used to classify whole roots into two levels of maggot damage $(\leq 8 \%$ or $>8 \%$ ) based on the area of the tunnels formed by maggot feeding on the root surface. Maggot feeding was often confirmed by the presence of cabbage maggot fly pupae embedded in the tunnels of many of these roots. After assessing for the level of maggot damage, roots were classified into four 
categories of root rot based on the rating scale developed by Gugel et al. (3; Table 1). As a result, there were eight categories for estimating levels of root rot and maggot damage. Plants with a root stub due to severe root rot (5 on the root rot rating scale) were placed into an additional category (ninth) for which it was not possible to determine maggot damage.

Yield assessment. Plant biomass, including the taproot, seed yield, and seed size (1,000 seed weight), were determined for each damage class at each site. Oil content was determined on a Newport NMR analyzer MKIIIA (Oxford Analytical Instruments, Oxfordshire, U.K.) using the methods of Madsen (6). Because not all samples for BGRR5 contained a sufficient amount of seed (i.e., $20 \mathrm{~g}$ ) required for oil content determinations, three bulked samples were formed by combining the seed across maggot damage and several sites and/or farms. For other root rot levels, samples were also bulked across maggot damage and the same combinations of sites and/or farms used for bulking BGRR5. For example, one replicate in 1999 was formed by combining the seed across the two levels of maggot damage from two sites of one grower's field (A) and an additional site of another grower's field (B-1) such that the bulked sample contained at least $20 \mathrm{~g}$ of seed. This combination of two sites of one grower's field (A-1 and A2) and one site of another grower's field (B1) was then used for all levels of BGRR. The effect of maggot damage on oil content was not determined.

Data analysis. Before statistical analyses were conducted, plant biomass and seed yields were divided by the number of plants in each maggot-damage-root-rot category to adjust for unequal numbers. In addition, harvest index, which is the ratio

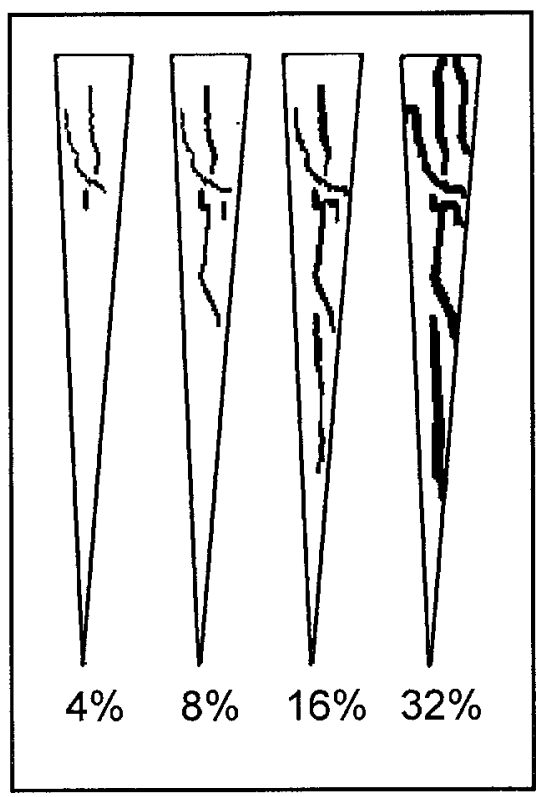

Fig. 1. Standard area diagrams generated by computer to assess maggot damage on canola roots. of the seed yield to the total harvested plant biomass, was calculated. All parameters were subjected to analysis of variance using PROC GLM procedures of the SAS statistical software package (SAS Institute, Inc., Cary, NC).

A series of hypotheses were tested. First, for each year or cultivar, a test for the effect of the root rot by maggot damage interaction was conducted excluding the data for the ninth category and using the model, $y=F_{i}[i=1, \ldots, 6]+S_{j}\left(F_{i}\right)[j=1,2]+B_{k}[k$ $=1,2,3,4]+M_{l}[l=1,2]+B_{k}^{*} M_{l}$, where $F$ is the commercial field, $S$ is the site, $B$ is the level of root rot, and $M$ is the level of maggot damage. If there was no significant maggot by root rot interaction, data for plant biomass and seed yields from each root rot class were combined over all maggot classes and readjusted for the total numbers of plants in a root rot class. The null hypothesis that there were no effects of root rot class on a given parameter was tested including the data from BGRR5 (i.e., $y=F_{i}+S_{j}\left(F_{i}\right)+B_{k}$ where $I=[1, \ldots, 6]$, $j=[1,2]$, and $k=[1,2,3,4,5])$. To determine whether the effects of maggot or root rot depended on year, analyses for Tobin were performed on the combined data and using the model $y=\operatorname{Yr}_{i}+P_{j}\left(\mathrm{Yr}_{i}\right)+X_{k}+X_{k}{ }^{*} \mathrm{Yr}_{i}$ where $\mathrm{Yr}$ is the year $(i=1,2), P_{j}$ is the plot $(j=1,2)$, and $X$ is the level of maggot damage $(k=1,2)$ or BGRR $(k=1,2, \ldots, 5)$.

Since it is not appropriate to perform regression analyses on these data because the root rot classes are only descriptive, multiple comparisons were performed using Tukey's test. Chi-square analyses were performed to test whether the number of roots in a root rot class was independent of the level of maggot damage. To ensure an adequate number of roots in each cell of the root rot class (BGRR1 to BGRR4) by maggot damage category (M1-M2) contingency table, roots were summed over all farms for each year.

Table 1. Categories used for root rot ratings

\begin{tabular}{ll}
\hline Rating & Description \\
\hline 1 & $\begin{array}{c}\text { Healthy, or small }(1 \mathrm{~mm}), \text { water-soaked, yellow lesions at or above the main lateral root, } \\
\text { and/or brown nongirdling lesions below the main lateral root } \\
\text { Brown, nongirdling lesions at or above the main lateral root, and/or girdling and non- } \\
\text { sinking lesion below the main lateral root }\end{array}$ \\
3 & $\begin{array}{c}\text { Nonsinking but girdling lesion at or above the main lateral root, and/or sinking and gir- } \\
\text { dling lesion below the main lateral root }\end{array}$ \\
4 & $\begin{array}{c}\text { Sinking girdling lesion at or above the main lateral root, and/or root part below the main } \\
\text { lateral root decayed }\end{array}$ \\
5 & Taproot decayed at or above the main lateral root with only a short stub remaining \\
\hline
\end{tabular}

Table 2. Analysis of variance of plant biomass, seed yield, seed size, and harvest index for canola cultivars Horizon and Reward

\begin{tabular}{|c|c|c|c|c|c|}
\hline Source & df & $\begin{array}{c}\text { Plant } \\
\text { biomass }\end{array}$ & Seed yield & Seed size & $\begin{array}{c}\text { Harvest } \\
\text { index }^{x}\end{array}$ \\
\hline \multicolumn{6}{|l|}{ Cultivar Horizon } \\
\hline \multicolumn{6}{|l|}{ Analysis $1^{\mathrm{y}}$} \\
\hline Field & 5 & 137.50 & 15.77 & 4.57 & 0.371 \\
\hline Site (field) & 6 & 62.21 & 2.86 & 0.43 & 0.007 \\
\hline BGRR & 3 & $58.85 \mathrm{~ns}^{\mathrm{z}}$ & $3.11 \mathrm{~ns}$ & $0.06 \mathrm{~ns}$ & $0.000 \mathrm{~ns}$ \\
\hline Maggot & 1 & $343.66 * *$ & $20.84 * *$ & $0.01 \mathrm{~ns}$ & $0.000 \mathrm{~ns}$ \\
\hline BGRR $\times$ maggot & 3 & $64.79 \mathrm{~ns}$ & $3.41 \mathrm{~ns}$ & $0.20 \mathrm{~ns}$ & $0.006 \mathrm{~ns}$ \\
\hline Error & 72 & 523.87 & 32.92 & 2.71 & 0.072 \\
\hline \multicolumn{6}{|l|}{ Analysis 2} \\
\hline Field & 5 & 129.96 & 5.61 & 2.82 & 0.028 \\
\hline Site (field) & 6 & 18.98 & 1.29 & 0.38 & 0.008 \\
\hline BGRR & 4 & $15.71 \mathrm{~ns}$ & $11.48 * *$ & $0.74 * *$ & $0.106 * *$ \\
\hline Error & 42 & 106.54 & 3.54 & 1.24 & 0.054 \\
\hline \multicolumn{6}{|l|}{ Cultivar Reward } \\
\hline \multicolumn{6}{|l|}{ Analysis 1} \\
\hline Field & 5 & 146.18 & 9.75 & 4.28 & 0.065 \\
\hline Site (field) & 6 & 19.23 & 1.26 & 1.43 & 0.026 \\
\hline BGRR & 3 & $6.06 \mathrm{~ns}$ & $1.20 \mathrm{~ns}$ & $0.43 * *$ & $0.005 *$ \\
\hline Maggot & 1 & $99.93 * *$ & $5.03 * *$ & $0.33 * *$ & $0.000 \mathrm{~ns}$ \\
\hline BGRR $\times$ maggot & 3 & $7.03 \mathrm{~ns}$ & $0.40 \mathrm{~ns}$ & $0.08 \mathrm{~ns}$ & $0.000 \mathrm{~ns}$ \\
\hline Error & 71 & 134.56 & 10.65 & 0.87 & 0.03 \\
\hline \multicolumn{6}{|l|}{ Analysis 2} \\
\hline Field & 5 & 114.16 & 6.72 & 2.61 & 0.033 \\
\hline Site (field) & 6 & 8.69 & 0.3 & 1.24 & 0.008 \\
\hline BGRR & 4 & $86.21 * *$ & $13.62 * *$ & $2.71 * *$ & $0.101 * *$ \\
\hline Error & 43 & 42.73 & 3.13 & 0.72 & 0.275 \\
\hline
\end{tabular}

${ }^{x}$ Quotient of seed yield and plant weight.

${ }^{y}$ In the first analysis, the brown girdling root rot (BGRR) by maggot interaction was not significant, so in the second analysis, plants within a BGRR rating were combined over the two levels of maggot damage. The second analysis included the data for BGRR5.

$\mathrm{z} *=$ significant at $P=0.05 ; * *=$ significant at $P=0.01 ;$ ns $=$ not significant. 
Yield losses, in the commercial fields of this study, were calculated using relative yield estimated for each root rot category in the formula:

$$
1-\frac{\sum_{i=1}^{5} n_{i} C_{i}}{\sum_{i=1}^{5} n_{i}}
$$

where $n_{i}$ is the number of plants in the $i$ th category and $C_{i}$ is the relative yield coefficient for the $i$ th category.

\section{RESULTS}

Yield from individual plants with low levels of root rot (BGRR1 and 2) was a linear function of plant weight. The harvest index, as determined from the slope of the regression line, was $0.293 \pm 0.003(n=72$, $\left.R^{2}=98\right)$ in 1998 and $0.279 \pm 0.006(n=$ $\left.191, R^{2}=95\right)$ in 1999 . The harvest index was not affected by root rot in $1998(0.299$ $\pm 003, n=18, P>0.50$ ), but in 1999 , this index was significantly less for plants with high levels of root rot (BGRR $>3,0.256 \pm$ $0.014, n=8, P<0.01$ ) than for plants with low levels of root rot. Although the variance in seed yield increased with plant biomass, this variation was small $(\mathrm{CV}<$ $5 \%$ ), and there were no nonlinear trends when the residuals of plant biomass were plotted. These results indicated that harvest index does not vary with plant size.

The results of the analysis of variance are shown in Table 2 for Horizon and Reward and in Table 3 for Tobin. In the first analysis, which excluded the effects of BGRR5, BGRR had a significant effect only on seed size and harvest index on Reward and seed size on Tobin. There were no significant effects of BGRR on the other variables. Generally, maggot damage had a significant effect on plant weight and seed yields, but not on harvest index and seed size. The BGRR by maggot damage interaction was not significant for any variable on Horizon or Reward. For Tobin, the data were combined for the 2 years, because results were similar in the 2 years and the year by maggot or root rot class interaction was not significant. For Tobin, there were no roots in the BGGR4 of the $>8 \%$ maggot damage class collected from the two plots in 1998, and from one of two sites in 1999, so the data from one plot in 1999 with roots at both levels of maggot damage were used to estimate the root rot by maggot damage interaction. In this analysis, the root rot by maggot damage interaction was not significant for any variable on Tobin. The year by root rot interaction and the BGRR rating by maggot damage class interaction were not significant for all parameters measured $(P>$ 0.05), so the effects of BGRR and maggot damage on yield were examined separately. In the second analysis, which involved only the effects of BGRR and included the BGRR5 level, root rot had a significant effect on all variables for all three cultivars, except biomass for Horizon.
Only severe brown girdling root rot had any effects on yield and its components. For all cultivars, seed yield, plant biomass, harvest index, seed size, and oil content were not different for plants in the lowest three categories of BGRR (Table 4). Except for plant biomass for Tobin, all plant measurements were not significantly different among BGRR1 to 4, but were significantly greater than BGRR5 except for plant biomass on Horizon. For Horizon and Reward, plant weight, seed yield, harvest index, and seed size were reduced on average by $31,63,18$, and $44 \%$, respectively, by BGRR category 5 compared with BGRR categories 1 through 4 (Table 4).
The reductions were greater on Tobin than on Horizon and Reward for some plant measurements. For Tobin, the mean reductions were $55 \%$ for plant weight, $66 \%$ for seed yield, $28 \%$ for harvest index, and $28 \%$ for seed size in BGRR category 5 compared with the mean reductions of BGRR categories 1 through 4 (Table 4). The effect of root rot on seed oil content was not significant (Table 4).

Yield losses in commercial fields were estimated using equation 1 . Based on the relative yields estimated by combining all data in each root rot class, the coefficients for the yield loss equation were $1,0.85$, and 0.35 for root rot classes 1 to 3,4 , and

Table 3. Analysis of variance of plant biomass, seed yield, seed size, and harvest index of canola cultivar Tobin

\begin{tabular}{|c|c|c|c|c|c|}
\hline Source & df & $\begin{array}{c}\text { Plant } \\
\text { biomass }\end{array}$ & Seed yield & Seed size & $\begin{array}{c}\text { Harvest } \\
\text { index }^{x}\end{array}$ \\
\hline \multicolumn{6}{|l|}{ Analysis $1^{\mathrm{y}}$} \\
\hline Year & 1 & 0.56 & 0.12 & 0.018 & 0.0024 \\
\hline Site (year) & 2 & 43.98 & 5.94 & 0.134 & 0.0024 \\
\hline BGRR & 3 & $21.80 \mathrm{~ns}^{\mathrm{z}}$ & $1.61 \mathrm{~ns}$ & $0.039 *$ & $0.0006 \mathrm{~ns}$ \\
\hline Maggot & 1 & $13.02 \mathrm{~ns}$ & $2.01 *$ & $0.010 \mathrm{~ns}$ & $0.0006 \mathrm{~ns}$ \\
\hline BGRR $\times$ maggot & 3 & $10.42 \mathrm{~ns}$ & $1.66 \mathrm{~ns}$ & $0.018 \mathrm{~ns}$ & $0.0029 \mathrm{~ns}$ \\
\hline Year × BGRR & 3 & 1.46 & 0.02 & 0.004 & 0.0006 \\
\hline Year $\times$ maggot & 1 & 0.04 & 0.02 & 0.002 & 0 \\
\hline Year $\times$ BGRR $\times$ maggot & 2 & 1.56 & 0.02 & 0.034 & 0.0004 \\
\hline Error & 9 & 33.05 & 2.64 & 0.022 & 0.0028 \\
\hline \multicolumn{6}{|l|}{ Analysis 2} \\
\hline Year & 1 & 1.76 & 0.87 & 0.061 & 0.0061 \\
\hline Site (year) & 1 & 29.11 & 3.15 & 0.133 & 0.001 \\
\hline BGRR & 4 & $97.69 * *$ & $12.10 * *$ & $0.469 * *$ & $0.0212 * *$ \\
\hline Year $\times$ BGRR & 3 & $1.99 \mathrm{~ns}$ & $0.26 \mathrm{~ns}$ & $0.043 \mathrm{~ns}$ & $0.0037 \mathrm{~ns}$ \\
\hline Error & 8 & 28.06 & 0.58 & 0.094 & 0.0026 \\
\hline
\end{tabular}

${ }^{x}$ Quotient of seed yield and plant weight.

${ }^{y}$ In the first analysis the brown girdling root rot (BGRR) by maggot interaction was not significant, so in the second analysis plants within a BGRR rating were combined over the two levels of maggot damage. The second analysis included the data for BGRR5.

$\mathrm{z} *$ significant at $P=0.05 ; * *=$ significant at $P=0.01 ; \mathrm{ns}=$ not significant.

Table 4. Effect of brown girdling root rot (BGRR) on plant biomass, seed yield, seed size, harvest index, and oil content on canola cultivars Horizon, Reward, and Tobin

\begin{tabular}{|c|c|c|c|c|c|}
\hline $\begin{array}{l}\text { BGRR } \\
\text { rating }\end{array}$ & $\begin{array}{c}\text { Plant biomass } \\
\quad(g / \text { plant })\end{array}$ & $\begin{array}{l}\text { Seed yield } \\
\text { (g/plant) }\end{array}$ & $\begin{array}{c}\text { Seed size } \\
\left(\mathrm{g} / 10^{3} \text { seed }\right)\end{array}$ & $\begin{array}{l}\text { Harvest } \\
\text { index }^{x}\end{array}$ & $\begin{array}{c}\text { Oil content } \\
(\%)\end{array}$ \\
\hline \multicolumn{6}{|c|}{ Horizon ${ }^{y}$} \\
\hline 1 & $6.72 \mathrm{a}^{\mathrm{z}}$ & $1.74 \mathrm{a}$ & $2.02 \mathrm{a}$ & $0.26 \mathrm{a}$ & $45.7 \mathrm{a}$ \\
\hline 2 & $7.25 \mathrm{a}$ & $1.98 \mathrm{a}$ & $2.06 \mathrm{a}$ & $0.27 \mathrm{a}$ & $45.8 \mathrm{a}$ \\
\hline 3 & $7.27 \mathrm{a}$ & $1.94 \mathrm{a}$ & $2.09 \mathrm{a}$ & $0.27 \mathrm{a}$ & $46.5 \mathrm{a}$ \\
\hline 4 & $7.17 \mathrm{a}$ & $1.90 \mathrm{a}$ & $2.03 \mathrm{a}$ & $0.27 \mathrm{a}$ & $46.1 \mathrm{a}$ \\
\hline 5 & $5.85 \mathrm{a}$ & $0.74 \mathrm{~b}$ & $1.77 \mathrm{~b}$ & $0.15 \mathrm{~b}$ & $43.2 \mathrm{a}$ \\
\hline \multicolumn{6}{|c|}{ Rewardy } \\
\hline 1 & $8.21 \mathrm{a}$ & $2.02 \mathrm{a}$ & $2.49 \mathrm{a}$ & $0.25 \mathrm{a}$ & $43.9 \mathrm{a}$ \\
\hline 2 & $7.87 \mathrm{a}$ & $1.98 \mathrm{a}$ & $2.53 \mathrm{a}$ & $0.25 \mathrm{a}$ & $44.2 \mathrm{a}$ \\
\hline 3 & $7.59 \mathrm{a}$ & $1.93 \mathrm{a}$ & $2.42 \mathrm{a}$ & $0.26 \mathrm{a}$ & $44.9 \mathrm{a}$ \\
\hline 4 & $7.18 \mathrm{a}$ & $1.69 \mathrm{a}$ & $2.36 \mathrm{a}$ & $0.24 \mathrm{a}$ & $44.0 \mathrm{a}$ \\
\hline 5 & $4.55 \mathrm{~b}$ & $0.67 \mathrm{~b}$ & $1.94 \mathrm{~b}$ & $0.14 \mathrm{~b}$ & $43.2 \mathrm{a}$ \\
\hline \multicolumn{6}{|l|}{ Tobin ${ }^{y}$} \\
\hline 1 & $12.25 \mathrm{a}$ & $3.45 \mathrm{a}$ & $2.26 \mathrm{a}$ & $0.29 \mathrm{a}$ & $44.6 \mathrm{a}$ \\
\hline 2 & $11.32 \mathrm{a}$ & $3.27 \mathrm{a}$ & $2.32 \mathrm{a}$ & $0.29 \mathrm{a}$ & $44.5 \mathrm{a}$ \\
\hline 3 & $11.36 \mathrm{a}$ & $3.05 \mathrm{a}$ & $2.28 \mathrm{a}$ & $0.30 \mathrm{a}$ & $45.3 \mathrm{a}$ \\
\hline 4 & $8.15 b$ & $2.37 \mathrm{a}$ & $2.18 \mathrm{a}$ & $0.29 \mathrm{a}$ & $45.0 \mathrm{a}$ \\
\hline 5 & $5.20 \mathrm{~b}$ & $1.1 \mathrm{~b}$ & $1.64 \mathrm{~b}$ & $0.21 \mathrm{~b}$ & $45.0 \mathrm{a}$ \\
\hline
\end{tabular}

x Quotient of seed yield and plant weight.

${ }^{y}$ Entries are the means over all sites. There were two sites at each of six sampled fields for both Horizon in 1998 and Reward in 1999. For Tobin, entries are the means over all sites and years. There were two sites in both 1998 and 1999.

${ }^{\mathrm{z}}$ Means within a column for each cultivar followed by the same letter are not significantly different according to Tukey's test $(P=0.05)$. 
Table 5. Effect of maggot damage on plant biomass, seed yield, seed size, and harvest index of canola cultivars Horizon, Reward, and Tobin

\begin{tabular}{|c|c|c|c|c|}
\hline Maggot damage & $\begin{array}{c}\text { Plant biomass } \\
\text { (g/plant) }\end{array}$ & $\begin{array}{l}\text { Seed yield } \\
\text { (g/plant) }\end{array}$ & $\begin{array}{c}\text { Seed size } \\
\left(\mathrm{g} / \mathbf{1 0}^{3} \text { seed }\right)\end{array}$ & Harvest index $x$ \\
\hline \multicolumn{5}{|l|}{ Horizon ${ }^{y}$} \\
\hline$\leq 8 \%$ & $7.25 \mathrm{a}^{\mathrm{z}}$ & $1.83 \mathrm{a}$ & $2.50 \mathrm{a}$ & $0.25 \mathrm{a}$ \\
\hline$>8 \%$ & $9.46 \mathrm{~b}$ & $2.35 \mathrm{~b}$ & $2.38 \mathrm{a}$ & $0.25 \mathrm{a}$ \\
\hline \multicolumn{5}{|l|}{ Rewardy } \\
\hline$\leq 8 \%$ & $6.83 \mathrm{a}$ & $1.82 \mathrm{a}$ & $2.04 \mathrm{a}$ & $0.27 \mathrm{a}$ \\
\hline$>8 \%$ & $11.09 \mathrm{~b}$ & $2.87 \mathrm{~b}$ & $1.99 \mathrm{a}$ & $0.26 \mathrm{a}$ \\
\hline \multicolumn{5}{|l|}{ Tobin ${ }^{y}$} \\
\hline$\leq 8 \%$ & $10.97 \mathrm{a}$ & $3.17 \mathrm{a}$ & $2.30 \mathrm{a}$ & $0.29 \mathrm{a}$ \\
\hline$>8 \%$ & $12.87 \mathrm{~b}$ & $3.82 \mathrm{~b}$ & $2.28 \mathrm{a}$ & $0.30 \mathrm{a}$ \\
\hline
\end{tabular}

${ }^{x}$ Quotient of seed yield and plant weight.

${ }^{y}$ Entries are the means over root rot levels brown girdling root rot (BGRR) 1 to 4 and all sites. There were two sites in each of the six commercial fields sampled for both Horizon in 1998 and Reward in 1999. There were two sites in both 1998 and 1999 for Tobin.

${ }^{\mathrm{z}}$ Means within a column for each cultivar followed by the same letter are not significantly different according to Tukey's test $(P=0.05)$.
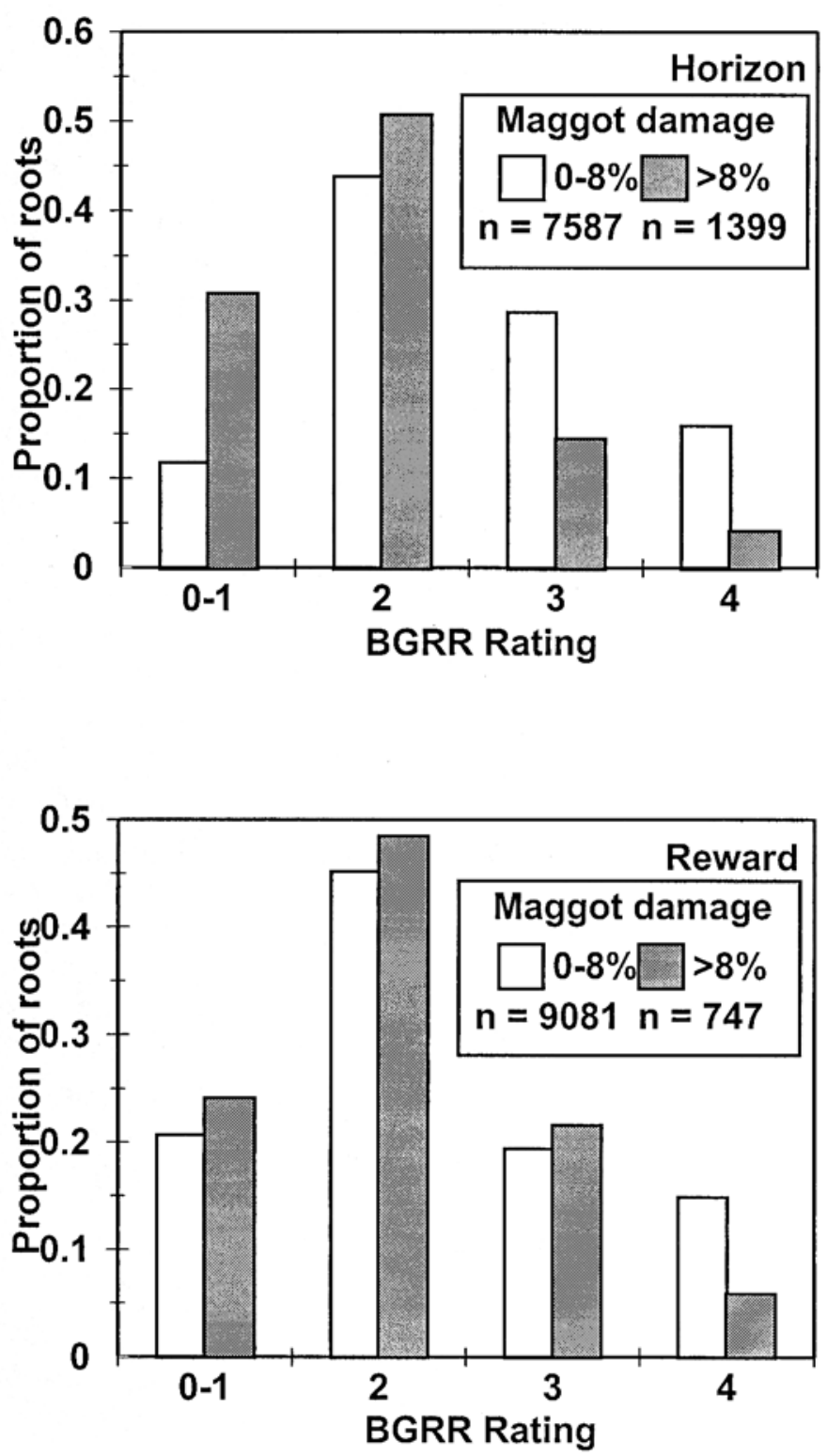

Fig. 2. Distribution of brown girdling root rot (BGRR) ratings on canola roots with low $(\leq 8 \%)$ or high $(>8 \%)$ maggot damage on cultivar Horizon in 1998 and on cultivar Reward in 1999. BGRR ratings according to Gugel et al. (3): $1=$ small lesions $(<1 \mathrm{~mm}) ; 2=$ brown nongirdling lesions; $3=$ nonsinking girdling lesions; 4 = sinking girdling lesions; $5=$ stub root.
5, respectively. Based on the observed distributions of root rot, yield losses for the growers fields ranged from 0.9 to $5.0 \%$ ( $\bar{x}$ $=2.7 \%)$ in 1998 and from 0.5 to $5.4 \%(\bar{x}=$ $2.6 \%$ ) in 1999 .

In contrast to the effects of BGRR on yield, yield was not affected by the two levels of maggot injury on yield loss. Although plant weights and seed yields were significantly greater for plants with $>8 \%$ maggot damage than for plants with $\leq 8 \%$ maggot damage, the level of maggot injury had no effect on the harvest index or seed size (Table 5).

Maggot injury, which did not exceed $32 \%$ of the root area, did not increase root rot levels. Roots with $>8 \%$ maggot damage comprised 15.1 and $7.6 \%$ of total roots collected for Horizon and Reward, respectively. For Tobin, the roots with $>8 \%$ comprised $24.1 \%$ of the total in 1998 and $12.6 \%$ in 1999 . In both years, the incidence of girdled roots (BGRR3 and BGRR4) was less on roots with $>8 \%$ maggot damage than on roots with $\leq 8 \%$ maggot damage for Horizon and Reward (Fig. 2) and Tobin (Fig. 3). Chi-square analyses revealed that these differences in the distribution of girdled roots were significant $\left(X^{2} \geq 50.4 ; P\right.$ $<0.05$ ) for both cultivars in both 1998 and 1999.

\section{DISCUSSION}

Since the single plant harvest index for plants with low levels of root rot (BGRR1 to 3) was constant for plants of various weights and, presumably, different plant sizes, it is feasible to use this index to interpret results of root rot and maggot damage on seed yield, especially in cases where there is a large variation in plant sizes in a sample. For example, although both plant biomass and seed yields were greater on plants with $>8 \%$ maggot damage than on plants with $\leq 8 \%$ maggot damage, harvest index in addition to seed size can be used to indicate that maggot injury had no effect on yield.

Brown girdling root rot had a significant impact on single plant yield. Yield loss was not associated with either a girdling nonsinking superficial lesion on the upper root or a sinking girdling lesion on the taproot below the main lateral root (BGRR1 to 4). Yield was reduced on plants with completely decayed roots (BGRR5). Although plant biomass was also reduced by BGRR5, the reduction in harvest index indicated that the effects of root rot were greater on seed yields than on plant biomass because harvest index is not affected by plant size at low root rot levels. This yield reduction was partly explained by the effect of root rot on seed size. However, because the harvest index for BGRR5 compared with BGRR1 to 4 was less than the product of the respective ratios for plant biomass (a measure of potential plant yield) and seed size (a yield component), other yield components, including seeds 
per pod and pods per plant, are also likely important. In fact, some samples in the BGRR5 class contained a few dead plants with few or no pods.

Brown girdling root rot may have a significant impact on yields in commercial canola fields. In this study, estimated crop yield losses were small. Because the pathogen is favored by cool and wet seasons $(10,14)$, crop yield losses are expected to be higher under these conditions than under the dry weather conditions encountered in 1998 and 1999. Crop yields based on the single plant estimates may be biased due to yield compensation on healthy plants. Compensation occurs because these plants take advantage of space and resources unused by their diseased neighbors. However, because plants were sampled from blocks, the effects of compensation are probably included in the single plant yield estimates and consequently in the yield estimates of the commercial fields.

In this study, plant biomass and seed yields were greater on plants with $>8 \%$ maggot damage than on plants with $\leq 8 \%$ maggot damage. These results are in agreement with previous studies that concluded that maggot flies preferentially select plants with large basal stem diameters that produce higher seed yields (2). Because of this preferential feeding habit, it is difficult to make any conclusions on the effect of maggot damage on yield based on plant biomass and seed yields alone. But harvest index and seed size, which do not vary with size of the plant, are a better indication of the impact of maggot damage on yield. Since seed size and harvest index were not different, the levels of maggot damage observed in this study did not contribute to yield loss. Other studies also have concluded that there is little reduction in seed yield of canola due to low levels of maggot injury $(7,8)$. In the absence of maggot-initiated root rot, maggots would not be expected to increase yield loss because maggot injuries rarely extend into the center of the root (9).

It may be concluded that BGRR, but not low levels of maggot damage, is an important constraint to canola production. Because it was not possible to assess roots in the BGRR5 class for maggot damage, it is possible that both pests may have interacted, leading to a further reduction in yield than that attributed to BGRR alone. Additional research is required to determine the effects of levels of maggot damage greater than $32 \%$, which were rarely observed in this study, and its interaction with BGRR on yield loss.

There was no apparent interaction between maggot injury and BGRR on yield. It may be expected that maggot injuries could compound the losses in yield since they provide entry points for infection by root rot pathogens, but this has not always been the case. In one study on cruciferous vegetables, there was an increase in soft rots due to cabbage root maggot (1), but in Manitoba, there was no association between foot rots and cabbage root maggot on canola (13). Studies on other pathosystems also revealed no association. For example, in the ginger rhizome-Pythium aphanidermatum pathosystem, the incidence of rhizome rot was independent of rhizome maggot severity (5). Although there was some visual evidence of root discoloration that was usually confined to the maggot tunnels, there is little evidence to support the hypothesis that brown girdling root rot increases with maggot damage in canola. In fact, there were proportionally more roots in the BGRR1 and BGRR2 categories for the $>8 \%$ maggot severity class than for the $\leq 8 \%$ maggot severity class in both 1998 and 1999. Thus, at harvest, maggot damage and brown girdling root rot are not positively associated. One hypothesis is that maggot inju-
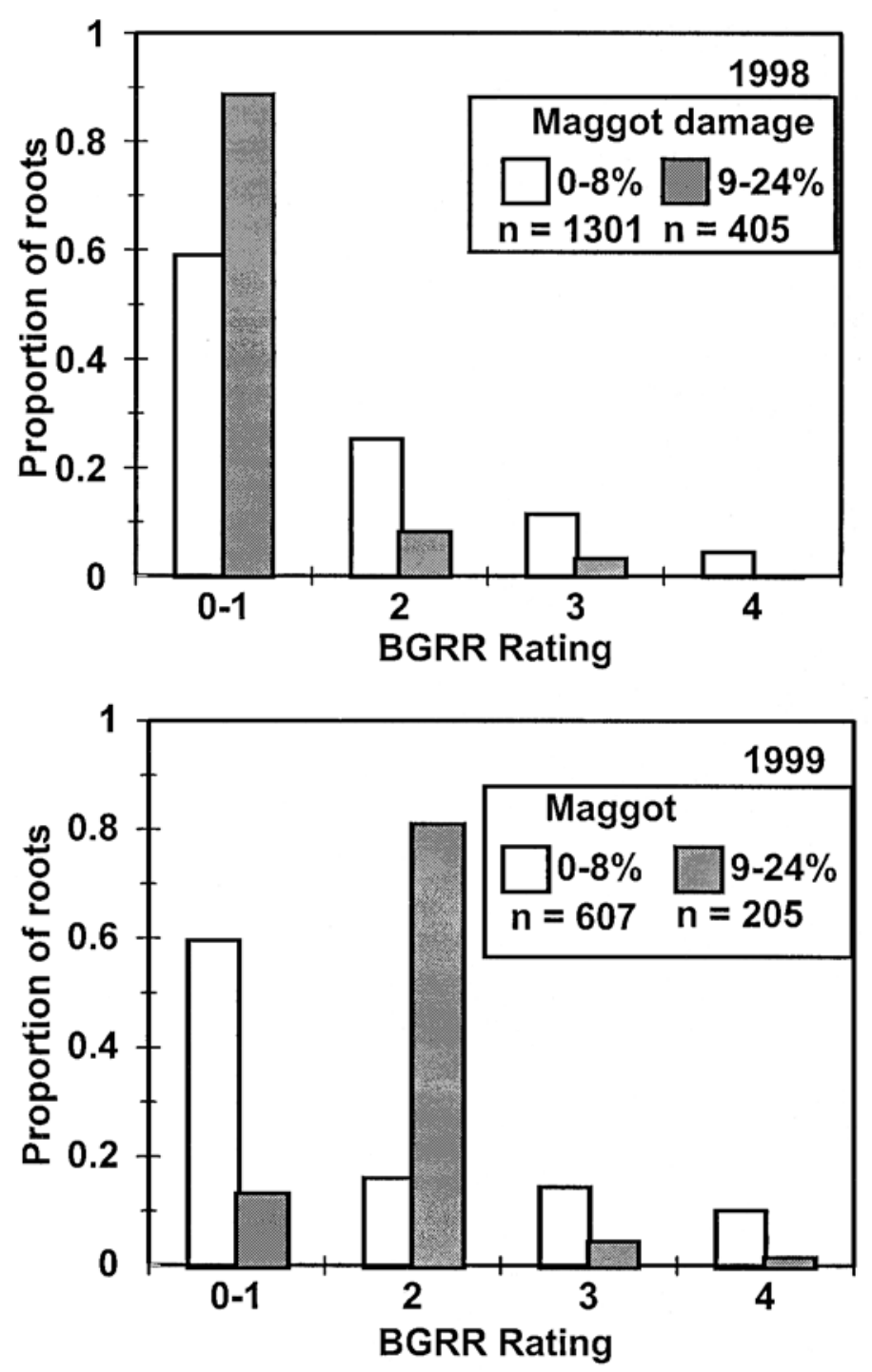

Fig. 3. Distribution of brown girdling root rot (BGRR) ratings on canola roots with low $(\leq 8 \%)$ or high (>8\%) maggot damage on Tobin in 1998 and 1999. BGRR ratings according to Gugel et al. (3): $1=$ small lesions $(<1 \mathrm{~mm}) ; 2=$ brown nongirdling lesions; $3=$ nonsinking girdling lesions; $4=$ sinking girdling lesions; $5=$ stub root. ries may stimulate other defense mechanisms to protect the injured root region from invasion by soil fungi. Further research is required to elucidate the reason for this apparent negative association.

Plants with roots girdled by sinking lesions sustain an average single plant yield loss of $17 \%$, and plants with decayed roots sustain an average yield loss of $65 \%$ compared with plants with no or low levels of root rot. Furthermore, yield loss was not compounded by the low levels of maggot damage encountered. Although these conclusions are based on a number of experiments over time, further research is required to determine the interaction of cultivar, maggot damage class, and root rot class on single plant yield loss. In addition, more studies are required to determine the relationship of seed yield and plant biovides a useful parameter to detect yield loss. mass and to verify that harvest index pro- 


\section{ACKNOWLEDGMENTS}

Financial support from the Alberta Canola Producer's Commission and the Alberta Agricultural Research Institute is gratefully acknowledged. The many comments and suggestions of the anonymous reviewers to improve the manuscript are also gratefully acknowledged. We also acknowledge the excellent technical assistance of $\mathrm{H}$. Spence, C. Schmidt, and C. Fletcher.

\section{LITERATURE CITED}

1. Cerkauskas, R. F., Stobbs, L. W., Lowery, D. T., Van-Driel, L., Liu, W., and Van Schagen, J. 1998. Diseases, pests, and abiotic problems associated with oriental cruciferous vegetables in Southern Ontario in 1993-1994. Can. J. Plant Pathol. 20:87-94.

2. Dosdall, L. M., Herbut, M. J., Cowle, N. T., and Micklich, T. M. 1996. The effect of tillage regime on emergence of root maggots (Delia spp.) (Diptera: Anthomyiidae) from canola. Can. Entomol. 128:1157-1165.

3. Gugel, R. K., Yitbarek, S. M., Verma, P. R., Morrall, R. A. A., and Sadasivaiah, R. S. 1987. Etiology of the rhizoctonia root rot complex of canola in the Peace River region of Alberta. Can. J. Plant Pathol.
9:119-128.

4. Harper, F. R., and Berkenkamp, B. 1975. Revised growth-stage key for Brassica campestris and B. napus. Can. J. Plant Sci. 55:657-658.

5. Koya, K. M. A. 1990. Role of rhizome maggot Mimegralla coeruleifrons Macquart in rhizome rot of ginger. Entomon. 15:75-78.

6. Madsen, E. 1976. Nuclear magnetic resonance spectrometry as a quick method of determination of oil content in rapeseed. J. Am. Oil Chem. Soc. 53:467-469.

7. McDonald, R. S., and Sears, M. K. 1991. Effects of root damage by cabbage maggot, Delia radicum (L.) (Diptera: Anthomyiidae), on yield of canola, Brassica campestris L., under laboratory conditions. Can. Entomol. 123:861-867.

8. McDonald, R. S., and Sears, M. K. 1992. Assessment of larval feeding damage of the cabbage maggot (Diptera: Anthomyiidae) in relation to oviposition preference on canola. J. Econ. Entomol. 85:957-962.

9. Mowry, T. M. 1993. Ovipositional patterns and larval movement of Delia antiqua (Diptera: Anthomyiidae) on sprouted bulb and seedling onions. J. Econ. Entomol. 86:14401445 .

10. Teo, B. K., Yitbarek, S. M., Verma, P. R., and Morrall, R. A. A. 1988. Influence of soil moisture, seeding date, and Rhizoctonia solani (AG 2-1 and AG 4) on disease incidence and yield in canola. Can. J. Plant Pathol. 10:151-158.

11. Turkington, T. K., and Harrison, L. M. 1994. Survey of canola diseases in the Peace River region of Alberta, 1993. Can. Plant. Dis. Surv. 74:94-95.

12. Turkington, T. K., and Woods, D. L. 1997. Yield loss as a result of brown girdling roo rot of canola. (Abstr.) Can. J. Plant Pathol. 19:118.

13. Turnock, W. J., Timlick, B., Galka, B. E., and Palaniswamy, P. 1992. Root maggot damage to canola and the distribution of Delia spp. (Diptera: Anthomyiidae) in Manitoba. Can. Entomol. 124:49-58.

14. Yitbarek, S. M., Verma, P. R., Gugel, R. K., and Morrall, R. A. A. 1988. Effect of soil temperature and inoculum density on preemergence damping-off of canola caused by Rhizoctonia solani. Can. J. Plant Pathol. 10:93-98. 